\title{
Critical role of extracellular vesicles in modulating the cellular effects of cytokines
}

Szabó $^{1}$, Géza Tamás; Bettina Tarr ${ }^{1}$; Krisztina Pálóczi ${ }^{1}$; Katalin Éder ${ }^{1}$; Ágnes Kittel ${ }^{3}$; Sára Tóth ${ }^{1}$; Bence György $^{1}$; Mária Pásztói ${ }^{1}$ Andrea Németh ${ }^{1}$; Xabier Osteikoetxea ${ }^{1}$; Éva Pállinger ${ }^{1}$; Katalin SzabóTaylor* ${ }^{1}$; Edit Irén Buzás ${ }^{1 \#_{*}}$

\section{*These authors contributed equally}

${ }^{1}$ Department of Genetics, Cell- and Immunobiology, Semmelweis University, Budapest, Hungary

${ }^{3}$ Institute of Experimental Medicine, Hungarian Academy of Sciences, Budapest, Hungary

\# corresponding author: edit.buzas@ gmail.com, Tel: +36-1-2102929, Fax: +36-1-3036968

Running title: Extracellular vesicles modulate cytokine effects 


\begin{abstract}
Under physiological and pathological conditions, extracellular vesicles (EVs) are present in the extracellular compartment simultaneously with soluble mediators. We hypothesized that cytokine effects may be modulated by EVs, the recently recognized conveyors of intercellular messages. In order to test this hypothesis, human monocyte cells were incubated with CCRF acute lymphoblastic leukemia cell line-derived EVs with or without the addition of recombinant human TNF, and global gene expression changes were analysed. EVs alone regulated the expression of numerous genes related to inflammation and signaling. In combination, the effects of EVs and TNF were additive, antagonistic or independent. The differential effects of EVs and TNF or their simultaneous presence were also validated by Taqman assays, ELISA and testing different populations of purified EVs. In the case of the paramount chemokine IL-8, we were able to demonstrate a synergistic up-regulation by purified EVs and TNF. Our data suggest that neglecting the modulating role of EVs on the effects of soluble mediators may skew experimental results. On the other hand, considering the combined effects of cytokines and EVs may prove therapeutically useful by targeting both compartments at the same time.
\end{abstract}

Key words: extracellular vesicle, inflammation, interleukin-8, microarray, TNF

\author{
Abbreviations \\ EV - extracellular vesicle \\ GSEA - Gene Set Enrichment Analysis \\ ICAM1 - intracellular adhesion molecule 1 \\ IL-8 - interleukin 8 \\ KEGG - Kyoto Encyclopedia of Genes and Genomes \\ TEM - transmission electron microscopy \\ TNF - tumor necrosis factor
}




\section{INTRODUCTION}

Extracellular vesicles (EVs) are membrane-surrounded structures. Based on their size and origin, EVs are broadly categorised into the following groups: exosomes, microvesicles (MVs) (also referred to as microparticles, shedding vesicles and ectosomes) and apoptotic bodies [1]. Although there is considerable overlap in the size distribution of the three main groups of EVs, exosomes are roughly 50-100 $\mathrm{nm}$ in size, and are generated by the exocytosis of multivesicular bodies. MVs (100-1000 nm) are produced by budding off the plasma membrane [1]. Apoptotic bodies are generally assumed to be larger, over $1000 \mathrm{~nm}$ in diameter, and are produced via membrane blebbing in the course of apoptosis, although EVs less than $1000 \mathrm{~nm}$ in diameter are also produced during apoptosis [1]. Several recent reviews summarise our current knowledge of EV physiology and analytical challenges of the field [15].

EVs have long been suspected to transfer messages between cells, and a number of different functions have been associated with EVs such as antigen presentation[6] and the transfer of mRNA and miRNA (,shuttle” RNA) [7]. EVs may communicate protective messages [8], promote inflammation [9], and their composition changes depending on the circumstances [10].

The stimulating effect of a T-cell-derived supernatant on the human monocyte cell line U937 was observed as early as 1983 [11]. A later study demonstrated that T-cell derived- EVs were able to activate human monocytes in a way similar to direct cell-to-cell contact [12].

However, most studies on EVs tend to focus on a single vesicle type, most frequently exosomes, and effects of different EV populations are rarely studied in combination. Furthermore, EVs and cytokines naturally occur in body fluids as a mixture, but no study to date has analysed the global gene expression effects of a combination of EVs and cytokines on cells.

We hypothesized that EVs modulate the cellular effects of cytokines. Here we show that the effects of EVs, TNF or their combination on gene expression of recipient cells are substantially different. 


\section{MATERIALS AND METHODS}

\section{Cell lines}

CCRF-CEM human T-cell lymphoma line and U937 human monocyte cell line were obtained from ATCC. The cell lines were cultured in RPMI medium (Sigma, Budapest, Hungary) containing 10\% (v/v) fetal bovine serum (PAA, Budapest, Hungary), $2 \mathrm{mM}$ glutamine, $100 \mathrm{U} / \mathrm{mL}$ each penicillin and streptomycin and occasionally $0.5 \%$ ciprofloxacin (Fresenius Kabi, Budapest, Hungary), at $37{ }^{\circ} \mathrm{C}$ in $5 \% \mathrm{CO}_{2} /$ air. The cell lines were regularly tested for mycoplasma contamination using a DAPI-based mycoplasma detection.

\section{Experimental setup}

All experiments were performed in quadruplicates, unless otherwise stated. CCRF cells were grown to confluency. For the experiment, cells were resuspended at $0.5 \times 10^{6}$ cells $/ \mathrm{ml}$ density in serum-free RPMI medium containing $0.5 \%$ ciprofloxacin, and EV production was allowed to take place for 24 hours. To avoid aggregation of EVs, co-sedimentation of protein aggregates with EVs and the potential damage of the membrane of EVs during high speed centrifugation, we chose a method for studying EVs that we expected to cause the least artefactual effects on EVs. Thus, the supernatant of cells was collected and treated as follows, in order to produce two different fractions: i) EV-containing, cell-free supernatant was prepared by centrifuging the supernatant for $10 \mathrm{~min}$ at $300 \mathrm{~g}$ and discarding the pellet; ii) EV-free, cell-free supernatant (control) was prepared by spinning the supernatant at $300 \mathrm{~g}$ for 10 min, followed by $20,500 \mathrm{~g} 20 \mathrm{~min}$ and $100,000 \mathrm{~g} 60 \mathrm{~min}$, harvesting the supernatant and filtering it through a $0.2 \mu \mathrm{m}$ filter (Millipore, Budapest, Hungary) by hydrostatic pressure.

The two different types of supernatants (total EV-containing and control) were divided in two aliquots each. Next, we added the EV-depleted or EV-containing supernatants (derived from 1 x $10^{6} \mathrm{CCRF}$ cells) to each of the wells of 6-well tissue culture plates. Parallel wells containing EV-depleted or EVcontaining supernatants were supplemented with 10ng/mL TNFa. (Sigma, Budapest, Hungary) U937 cells $\left(5 \times 10^{6}\right.$ cells per well in $5 \mathrm{ml}$ total volume) were added to each well of the plates. The cells were incubated for 24 hours at $37{ }^{\circ} \mathrm{C}$ in $5 \% \mathrm{CO}_{2}$ /air, harvested by spinning at $300 \mathrm{~g}$ for $5 \mathrm{~min}$ and washed once in PBS before RNA extraction. The supernatant was harvested and stored at $-80{ }^{\circ} \mathrm{C}$ until an ELISA analysis of IL-8 concentration was performed.

\section{Determination of EV concentration and size distribution using qNano}


Conditioned tissue culture supernatant of CCRF cells was centrifuged 300g 10 minutes, the pellet was discarded, and the supernatant was submitted to resistive pulse sensing analysis using a qNano instrument (IZON Science Ltd, New Zeland) as described before [13].

\section{Electron microscopy}

In order to characterize the vesicular composition of EV-containing supernatants, and to confirm that EV-free supernatants of CCRF cells did not contain any vesicular structures, we pelleted the conditioned media at 100,000 $\mathrm{g}$ for $60 \mathrm{~min}$. The supernatants were then carefully removed and the pellets were fixed with $4 \%$ paraformaldehyde in $0.01 \mathrm{M}$ PBS at room temperature for 60 minutes. Following washing with PBS, the preparations were postfixed in $1 \% \mathrm{OsO}_{4}$ (Taab) for 30 minutes. After rinsing with distilled water, the pellets were dehydrated in graded ethanol, including block staining with $1 \%$ uranyl-acetate in $50 \%$ ethanol for 30 minutes, and were embedded in Taab 812 (Taab). After overnight polymerization at $60^{\circ} \mathrm{C}$, the pellets were sectioned and the ultrathin sections were analyzed using a Hitachi 7100 electron microscope equipped with a Megaview II (lower resolution, Soft Imaging System) digital camera.

\section{Total RNA isolation}

Total RNA was isolated from U937 cells using a PureLink RNA Mini Kit (Ambion Life Sciences, Budapest, Hungary) according to the manufacturer's instructions. The purity and integrity of the RNA was analysed using Bioanalyzer RNA chips (Agilent, Kromat, Budapest, Hungary), and the RNA concentration was measured using a NanoDrop spectrophotometer.

\section{Microarray analysis}

Labelled cRNA was prepared according to the Agilent Low Imput QuickAmp Kit protocol and the 4x44k Whole Human Genom oligo microarray (Agilent, Kromat, Budapest, Hungary) was performed according to the protocol. Microarray data were analysed as outlined below.

The data discussed in this publication have been deposited in NCBI's Gene Expression Omnibus [14] and are accessible through GEO Series accession number GSE47897

(http://www.ncbi.nlm.nih.gov/geo/query/acc.cgi?acc=GSE47897).

Gene expression data generated by the microarray experiment were first analysed by Agilent's GeneSpring GX software. Three replicates of the following 4 types of samples were studied by the microarray: control, EV, EV+TNF, TNF, corresponding to treatments of U937 cells. Probes with less 
than two-fold mean change in expression value compared to the control, and probes with compromised flags, were excluded from further analysis. A one-way ANOVA test was performed on the remaining probes in order to detect significant alterations in gene expression, utilizing Tukey's post-hoc test and a Benjamini-Hochberg correction for multiple hypotheses. Corrected p values of less than 0.05 were considered statistically significant, unless otherwise stated.

\section{Reverse transcription and Taqman assays}

Following extraction the RNA was reverse transcribed: each $40 \mu 1$ reaction contained $2 \mu \mathrm{g}$ RNA, 5 $\mathrm{mM} \mathrm{MgCl} 2,10 \mathrm{mM} \mathrm{dNTP}$ (Promega, Budapest, Hungary), random primers (Promega) and $2 \mu \mathrm{ls}$ of 50 $\mathrm{U} / \mu 1 \mathrm{MuLV}$ reverse transcriptase (Roche, Budaörs, Hungary). The reaction was preformed in a Perkin Elmer DNA Thermal Cycler 480 under the following conditions: $42^{\circ} \mathrm{C} 40 \mathrm{~min}, 99^{\circ} \mathrm{C} 5 \mathrm{~min}, 20^{\circ} \mathrm{C} 5$ $\min$.

Quantitative real-time PCR of selected genes including HGPRT (endogenous control), CD36, CNR2, IL8, CCL2 was performed using Taqman probes and the reactions were run in an Applied Biosystems 7900HT Fast Real-Time PCR system using the thermal cycling conditions of 20 min at $95{ }^{\circ} \mathrm{C}$, followed by 40 cycles of $95{ }^{\circ} \mathrm{C} 1 \mathrm{~s}$ denaturation step and $60{ }^{\circ} \mathrm{C} 20 \mathrm{sec}$ annealing and extension step.

\section{Testing the effects of a combination of purified MVs and TNF on the IL-8 mRNA expression of U937 cells}

In order to validate the results of the somewhat unorthodox experimental setup used for the microarray experiment, we used purified CCRF-derived MVs $(20 \mu \mathrm{g} / \mathrm{ml})$ with or without TNF (10 ng/ml), resuspended in serum-free RPMI. MVs were purified using the following workflow: $300 \mathrm{~g} 10 \mathrm{~min} \rightarrow$ $2000 \mathrm{~g} 20 \mathrm{~min} \rightarrow$ filtration via an $800 \mathrm{~nm}$ filter by gravity $\rightarrow 12,500 \mathrm{~g} 10 \mathrm{~min}$. As a negative control, serum-free RPMI was used, with or without TNF (10 ng/ml). U937 cells were incubated for 24 hours at $37{ }^{\circ} \mathrm{C}$ in $5 \% \mathrm{CO}_{2}$ /air, harvested by spinning at $300 \mathrm{~g}$ for $5 \mathrm{~min}$ and washed once in PBS before RNA extraction, and IL-8 Taqman assays were carried out as described above.

\section{Interleukin-8 ELISA}

In order to confirm the detected gene expression changes on the protein level, interleukin-8 concentration was measured in the supernatant of treated U937 cells, a DuoSet ELISA development kit (R\&D Biosystems, Biomedica, Budapest, Hungary) was used, according to the manufacturer's instructions. 


\section{Statistical analysis}

Beyond the statistical analysis of the microarray results repeated measures ANOVA with Tukey's post test was used to analyse the data of the ELISA and Taqman assays by GraphPad Prism v.4. 


\section{RESULTS}

\section{Identification and characterization of EVs in CCRF supernatant}

In this study we used 24h conditioned medium of CCRF cells as a source of EVs. To confirm the presence of EVs and to characterize the EV composition, we first analyzed the 100,000 g pellets of cell-depleted CCRF supernatants by TEM. The pellet contained intact vesicles (Fig 1A) surrounded by continuous membrane mainly in the size range of MPs. Sporadically, some cup-shaped structures with morphological features of exosomes, at around $100 \mathrm{~nm}$ in diameters were also visible. Using ImageJ [15], the size distribution of vesicles in the EV pellet was calculated and was found to be $29-754 \mathrm{~nm}$, with a mean diameter of $212 \mathrm{~nm}$.

Next, an aliquot of the CCRF supernatant containing EVs was analysed using an NP200 membrane of IZON qNano, which detects particles with roughly over $150 \mathrm{~nm}$ diameter. The cell-free, EV-free medium contained virtually no particles, whereas the concentration of particles in the cell-free, EV-

containing medium was $2 \times 10^{8}$ particles $/ \mathrm{ml}$. The size range of particles was between 170-1250 nm, with a mean diameter of $380 \mathrm{~nm}(\mathbf{F i g} \mathbf{1 B})$. The discrepancy in the average particle diameter detected using qNano and ImageJ was possibly due to the differences in the detectable size range using the two methods.

Effects of EVs, human recombinant TNF or their combination on the gene expression of U937 cells

We next incubated U937 cells with EV-containing or EV-free CCRF human T-cell supernatant in the presence or absence of recombinant human TNF. The effects on gene expression were compared using an Agilent gene expression microarray.

\section{Single gene-based analysis by ANOVA, using GeneSpring}

After excluding compromised flags and filtering for at least 2-fold gene expression changes using ANOVA analysis, a statistically significant $(\mathrm{p}<0.05)$ difference in gene expression was found in the case of 202 probes, which could be mapped to 154 unique, annotated genes or loci (Fig. 2B). The mean expression values of these 154 genes were used in all downstream analysis apart from Gene Set Enrichment Analysis (GSEA) (where only compromised flags were excluded). The nature of gene expression changes of these 154 genes (i.e. up- or downregulation) following the different treatments were plotted on a Venn diagram (Fig. 2A). TNF treatment, EV treatment and combined treatment induced statistically significant changes in the case of 80,82 and 84 genes, respectively. 
A relatively large group of genes (51 genes) were up- or downregulated following treatment with EVs only. In comparison, the paramount cytokine TNF up- or downregulated the expression levels of as few as 16 genes (exclusive TNF effect) that did not change upon EV or combined EVs+TNF treatment.

A large number of genes (38) were upregulated following treatment with both TNF and TNF in combination with EVs. Among these were mainly inflammatory and anti-apoptotic molecules such as IL-8, ICAM-1, BCL3, and the chemokines CXCL10, CXCL11, CXCL3. Similarly, all treatments (EVs only, TNF only, combined EVs+TNF treatment) induced the upregulation of a number of inflammatory genes such as CCL2, CXCL2, RELB and FCAR.

\section{Cluster analysis of interaction patterns based on microarray results}

The pattern of interaction between cytokine and EV-related effects was further studied by K-means clustering, and we identified six clusters of significantly altered probes (ANOVA, p<0.05) (Fig. 3.).

Clusters \#1 and \#6: Here, the effect could be accounted for by EVs, and the effect of TNF alone was negligible. These clusters contained genes strongly upregulated (cluster 6, e.g. CNR2) or downregulated (cluster 1, e.g. MT1B, CXCL14, TBXAS1, SOCS2, CMYC) by EVs.

Cluster \#2: In this cluster genes were downregulated by both TNF and combined EVs+TNF treatment, but unaffected by EVs only.

Cluster \#3 and 5: These clusters contained genes where combined EVs+TNF treatment resulted in an additive effect compared to single treatments (TNF or EV). Cluster \#3 contained genes strongly upregulated by TNF, and the EVs contributed to this effect to a small extent (e.g. CXCL2, CXCL8, CXCL10 and MMP9). Cluster \#5 contained genes that were upregulated by both EVs and TNF to a small degree, but the combined effect was more pronounced (e.g. CCL2, CXCL3, CD36, CD82 and CHI3L1).

Cluster \#4: Here, effect of EVs on expression of these genes was negligible.

\section{GeneMania analysis and Gene set based analysis}

Next, in order to analyze interactions between genes, we used GeneMania plugin for Cytoscape to visualize co-expression, co-localization, genetic or physical interactions, as well as shared functions or domains. Following treatment with EVs only, the expression of IL8-like domain, Cytochrome P450 enzymes, proteins with T-SNARE domain or Furin repeat were changed (Fig. S1). Genes, significantly differentially regulated after combined EVs+TNF treatment, included transmembrane-G-proteincoupled receptors and chemokines with IL-8-like domain (Fig. 4A). 
For a less restricted analysis of biological significance of microarray results, gene set enrichment was studied on all non-compromised probes. After a screening for the number of enriched gene sets by the GSEA method, datasets based on Kyoto Encyclopedia of Genes and Genomes (KEGG) Pathways, Reactome, Chemical and Genetic Perturbations Database and Gene Ontologies were found to yield enriched gene sets. Regarding KEGG pathways, innate-like signaling pathways were most enriched in the presence of EVs. The top 60 genes of those sets only enriched after the combined EVs+TNF treatment, but not after TNF alone, were plotted against related, enriched GO terms (Fig. 4B). Many plasma membrane proteins, in particular cell surface receptors were differentially expressed after a combined EVs+TNF treatment.

\section{Experimental validation of the microarray results}

First, we carried out Taqman assays to confirm the microarray data on the expression changes of a select group of genes (Fig. 5A). Both TNF and the combined EVs+TNF treatment upregulated the expression of CCL-2. An additive effect of EVs and TNF was observed both in the case of IL-8 and CCL-2 mRNA levels. EV-containing supernatant caused a significant upregulation of CNR2 gene compared with EV-free supernatant and this enhancing effect was significantly diminished by the addition of TNF. TNF alone caused a tendency to decrease mRNA levels of this gene. Similar tendencies were observed in the case of CD36, although only the difference between TNF and the combined EVs+TNF treatment was significant. Therefore, we propose that EVS and TNF had an antagonistic effect on the gene expression levels of CD36 and CNR2.

Next, we wanted to confirm changes of IL-8 expression at the protein level. Therefore, we measured interleukin-8 in the supernatant of U937 cells following treatment with EV-containing or EV-free supernatant \pm TNF $(n=6)$. The additive effect of the EV-containing supernatant and TNF on IL-8 protein production was statistically significant (repeated measures ANOVA, Tukey's post-test, $\mathrm{p}<0.01$ ) (Fig. 5B).

Finally we wanted to demonstrate that our observations could be reproduced using purified EVs also. To this end, we purified CCRF-derived MVs which we subsequently resuspended in RPMI medium. These MVs were used, with or without the addition of TNF (10 ng/ml), to treat U937 cells. Compared to the treatment with MVs or TNF only, the combined MPs+TNF treatment resulted in a statistically significant upregulation of IL-8 mRNA levels (Fig. 5C) that was substantially higher than those observed in the presence of either MVs or TNF alone.

Further experimental validation work is described and shown in Fig S3. 


\section{DISCUSSION}

Over the past half a century, numerous studies investigated the effects of soluble mediators in different in vitro settings to gain an insight to the functions of cytokines/chemokines. Approximately 15 years ago, a novel field evolved, demonstrating the presence and physiological/pathological significance of purified EV preparations in vitro for cellular effects. Even though in vivo soluble mediators and extracellular vesicles are present simultaneously in the extracellular space, up until now, their combined presence has not been taken into consideration. Thus, the present study was carried out to fill this gap.

In order to test cellular effects of EVs, it is widely accepted to use purified EVs. However, this approach requires caution because of the lack of quality control tests for EV integrity. A common problem with vesicle pellets is aggregation, which makes it difficult to ensure even EV load in different treatments. EVs, in particular MPs, may also get damaged in the course of serial ultracentrifugation (similar to necrosis of cells). A third common confounding factor is co-pelleting of protein aggregates with EVs [16]. Furthermore, using pellets results in testing concentrated vesicles. For these reasons, we treated recipient cells with cell-depleted supernatant of EV-donor cells. As a negative control, we used supernatant depleted both in cells and EVs. This way, we were able to dissect the effects of cytokines present in the supernatant from the effects of EVs. We proved the validity of this experimental design by reproducing the interaction of EVs and TNF using purified MPs. Intriguingly, treatment with a combination of purified MVs and TNF induced significantly higher IL-8 mRNA levels than treatment with MVs or TNF alone, producing a synergistic rather than additive effect. One possible explanation for this synergistic effect could have been binding of TNF on the surface of MPs, since TNF has been shown to associate with EVs [17]. However, we were able to experimentally rule out this possibility (Fig. S3B). Therefore, we speculated that convergent signaling pathways rather than TNF accumulation on the surface of MVs were responsible for the observed additive/synergistic effect. There might be several possible explanations for the synergism between the effect of TNF and EVs. In case of IL-8, one possible mechanism suggested by GSEA analysis involves the upregulation of nuclear factor NF-kappaB, which acts both upstream of IL-8 and downstream of TNF. In another set of GSEA analyses (focusing on transcription factors that might induce the gene expression changes observed in the presence of EVs), sterol regulatory element-1 (SREBF1) appeared the most likely transcription factor responsible for the EV-induced effects. SREBF1 does not directly influence the gene expression of IL-8. However, according to GeneMania it physically interacts with CREB1, which is involved in the regulation of IL-8. This parallel signaling path could also potentially 
aid the upregulation of IL-8 in the presence of TNF. Yet another possibility for the modulating effect of EVs would be a mechanism involving their RNA cargo, mainly miRNAs. Although our bioinformatics approach, using miRwalk [18] did not result in any clue on a specific set of miRNAs that might be involved in the effect, this possibility can not be excluded.

Our study is the first to compare the effects of EVs in the presence or absence of a cytokine, on the global gene expression profile of recipient cells in a hypothesis-free system. Here we show that the presence of T-cell derived EVs or TNF alone, or in combination, causes differential gene expression patterns of U937 monocyte cells. The expression of 51 genes was statistically significantly altered following treatment with EVs compared to control. Thus, EVs are sufficient to regulate the expression of a large number of genes.

As demonstrated by a network of GO terms, a combined EVs+TNF treatment not only enhanced a cluster of inflammatory cytokines and members of the NF- $\mathrm{BB}$ pathway, but also caused a prominent effect on genes associated with cell surface receptor signaling, cytokine binding, membrane transport and genes associated with the plasma membrane (Fig. 4B, Fig. S2).

Interestingly, we found that the expression of only 16 genes was significantly altered due to the effects of TNF alone, compared to the control group. Most of the genes modulated by TNF ( 80 in total) in this study were also affected by a combined treatment with TNF and EVs, and EV treatment alone. This may suggest that EVs fine-tune the effects of TNF, and cross-talk exists between cytokines and EVs. Importantly, several anti-inflammatory genes were significantly upregulated by treatment with EVs. Thus, EVs, besides promoting the induction of inflammation, may also potentially contribute to the resolution of inflammation. A similar pattern of regulation was observed by Wahlgren et al [19] who looked at the combined effects of IL-2 and autologous exosomes on the cytokine profile of $\mathrm{T}$ lymphocytes. Conspicuously, we found that the genes repressed by treatment with EVs in this study outnumbered the genes enhanced by EV treatment. Furthermore, the number of repressed genes was also large (29) compared with the number of genes downregulated in the other treatments in this study. Exosomes transfer mRNA and microRNA between cells (termed exosomal shuttle RNA) [7], and a similar role of MVs has also been shown [20]. The extensive regulatory function of microRNAs in the immune system via repressing target genes, is well-known [21], and so microRNAs in EVs are potentially responsible for repressing target genes in recipient cells.

IL-8, a potent chemo-attractant for neutrophils, basophils and T cells, and an activator of neutrophils, appeared to be a central player in the effects of all treatments compared with control. Thus, we validated its expression at the mRNA and protein level also. The induction of IL-8 expression at the mRNA and protein levels in monocytes by EVs is in keeping with data by Baj-Krzyworzeka et al. 
[22]. These authors observed that tumour-derived MVs not only serve as a storage pool of IL-8 mRNA and protein, but also induce the de novo production of IL-8 and several CC cytokines (CCL2-5) by monocytes [22]. IL-8 production by synoviocytes was also induced by platelet-derived MVs in a seminal study on the role of platelet-derived MVs in arthritis [9].

GSEA results showed a strong association of the EV-regulated gene modules with those of a previous study on the effects of oxidised phospholipids on endothelial cells [23]. An interesting connection with the above study on oxidised phospholipids is our finding that treatment with EVs induced strong upregulation of CD36 (Fig. 5A). The scavenger receptor CD36 plays a variety of essential roles in the body. It recognises oxidised phospholipids [24], binds apoptotic cells via interacting with oxidised phosphatidylserine [25], and it also appears to be important in the uptake of vesicles. At least some of the binding of phosphatidylserine-containing vesicles to monocyte cells could be attributed to CD36 [26]. Therefore, it is not surprising that treatment with EVs caused an upregulation of one of their putative receptors.

The G-protein-coupled cannabinoid receptor 2 (CNR2, CB2) was strongly induced by treatment with EVs, and this effect was diminished by the additional presence of TNF. CNR2 is the "peripheral" cannabinoid receptor, mostly expressed by cells of the immune system and responsible for mediating the non-psychoactive effects of cannabinoids such as analgesia and immunosuppression [27]. Although relatively little is known about the cannabinoid receptors, CNR2 has evoked medical interest as an inducer of apoptosis, inhibitor of angiogenesis and skin tumour growth [28], and a potent antiinflammatory and immunosuppressive agent.[29]. CNR2 is also a target receptor of the dietary cannabinoid beta-caryophyllene, which, via the stimulation of CNR2, was able to achieve potent antiinflammatory effects in wild-type, but not in Cnr2-/- mice [30]. The potent upregulation of CNR2 by EVs may also reflect the anti-inflammatory effects of EVs.

This study proved that the combined effects of EVs and cytokines differ from their independent effects and points out that EVs likely modify the effects of inflammatory cytokines. The data presented her give a new insight into inflammatory processes. We propose that testing the combined effects of soluble mediators and extracellular vesicles may model the in vivo effects of these mediators on cells more accurately than testing them separately. Our data may provide an explanation why targeting of certain soluble mediators does not always lead to the desired therapeutic effects. Furthermore, uncoupling the interaction of EVs and soluble mediators may open a novel avenue for a more effective therapeutic intervention. 


\section{ACKNOWLEDGMENTS}

We are grateful for Ms Andrea Orbán's and Mrs Rita Antónia Fekete Heszné's excellent technical assistance. This work was funded by OTKA K 73247, OTKA NK 84043, OTKA PD104369, Baross Gábor (REG-KM-09-1-2009-0010) and Marie Curie Networks for Initial Training-ITN-FP7-PEOPLE-

2011-ITN, PITN-GA-2011-289033. Furthermore, this research was supported by TÁMOP 4.2.4. A/111-1-2012-0001 „National Excellence Program - Elaborating and operating an inland student and researcher personal support system" and subsidized by the European Union and co-financed by the European Social Fund."

\section{AUTHORSHIP CONTRIBUTIONS}

K.Sz.T., T.G.Sz. and B.T. designed and performed experiments, analysed data and wrote the manuscript. T.G.Sz. analysed the microarray data, K.P. and K.É. performed the microarray, Á.K. prepared the TEM images, S.T. provided support in tissue culture, B.Gy. and É.P. provided support for FACS analyses of preliminary experiments, A.N., X.O. and M.P. performed some of the experiments E.I.B. designed and supervised the study and wrote the manuscript.

\section{DISCLOSURE OF CONFLICTS OF INTEREST}

The authors declare no conflict of interest. 


\section{References}

1. György B, and Szabó, T, Pásztói M, Pál Z, Misják P, Aradi B, László V, Pállinger É, Pap E, Kittel Á, Nagy G, Falus A, Buzás E (2011) Membrane vesicles, current state-of-the-art: emerging role of extracellular vesicles. Cellular and Molecular Life Sciences 68 (16):2667-2688. doi:10.1007/s00018011-0689-3

2. Witwer KW, Buzás EI, Bemis LT, Bora A, Lässer C, Lötvall J, Nolte-'t Hoen EN, Piper MG, Sivaraman S, Skog J, Théry C, Wauben MH, Hochberg F (2013) Standardization of sample collection, isolation and analysis methods in extracellular vesicle research. Journal of Extracellular Vesicles 2 : 20360 http://dx.doi.org/10.3402/jev.v2i0.20360. doi:http://www.journalofextracellularvesicles.net/index.php/jev/article/view/20360

3. Gutiérrez-Vázquez C, Villarroya-Beltri C, Mittelbrunn M, Sánchez-Madrid F (2013) Transfer of extracellular vesicles during immune cell-cell interactions. Immunological Reviews 251 (1):125-142. doi:10.1111/imr.12013

4. van der Pol E, Böing AN, Harrison P, Sturk A, Nieuwland R (2012) Classification, Functions, and Clinical Relevance of Extracellular Vesicles. Pharmacological Reviews 64 (3):676-705. doi:10.1124/pr.112.005983

5. Raposo G, Stoorvogel W (2013) Extracellular vesicles: Exosomes, microvesicles, and friends. The Journal of Cell Biology 200 (4):373-383. doi:10.1083/jcb.201211138

6. Raposo G, Nijman HW, Stoorvogel W, Liejendekker R, Harding CV, Melief CJ, Geuze HJ (1996) B lymphocytes secrete antigen-presenting vesicles. The Journal of Experimental Medicine 183 (3):11611172. doi:10.1084/jem.183.3.1161

7. Valadi H, Ekstrom K, Bossios A, Sjostrand M, Lee JJ, Lotvall JO (2007) Exosome-mediated transfer of mRNAs and microRNAs is a novel mechanism of genetic exchange between cells. Nat Cell Biol 9 (6):654-659

8. Eldh M, Ekström K, Valadi H, Sjöstrand M, Olsson B, Jernös M, Lötvall J (2010) Exosomes Communicate Protective Messages during Oxidative Stress; Possible Role of Exosomal Shuttle RNA. PLoS ONE 5 (12):e15353

9. Boilard E, Nigrovic PA, Larabee K, Watts GFM, Coblyn JS, Weinblatt ME, Massarotti EM, Remold-O'Donnell E, Farndale RW, Ware J, Lee DM (2010) Platelets Amplify Inflammation in Arthritis via Collagen-Dependent Microparticle Production. Science 327 (5965):580-583. doi:10.1126/science.1181928

10. de Jong OG, Verhaar MC, Chen Y, Vader P, Gremmels H, Posthuma G, Schiffelers RM, Gucek M, van Balkom BWM (2012) Cellular stress conditions are reflected in the protein and RNA content of endothelial cell-derived exosomes. Journal of Extracellular Vesicles 1: 18396 - DOI: 10.3402/jev.v1i0.18396

11. Moscicki RA, Amento EP, Krane SM, Kurnick JT, Colvin RB (1983) Modulation of surface antigens of a human monocyte cell line, U937, during incubation with T lymphocyte-conditioned medium: detection of T4 antigen and its presence on normal blood monocytes. The Journal of Immunology 131 (2):743-748

12. Scanu A, Molnarfi N, Brandt KJ, Gruaz L, Dayer J-M, Burger D (2008) Stimulated T cells generate microparticles, which mimic cellular contact activation of human monocytes: differential regulation of pro- and anti-inflammatory cytokine production by high-density lipoproteins. Journal of Leukocyte Biology 83 (4):921-927. doi:10.1189/jlb.0807551

13. Patkó D, György B, Németh A, Szabó-Taylor K, Kittel Á, Buzás E, Horváth R (2013) Label-free optical monitoring of surface adhesion of extracellular vesicles Sensors and Actuators B in press

14. Edgar R, Domrachev M, Lash AE (2002) Gene Expression Omnibus: NCBI gene expression and hybridization array data repository. Nucleic Acids Research 30 (1):207-210. doi:10.1093/nar/30.1.207 
15. Rasband WS (1997-2012) ImageJ, http://imagej.nih.gov/ij/ U. S. National Institutes of Health, Bethesda, Maryland, USA

16. György B, Módos K, Pállinger É, Pálóczi K, Pásztói M, Misják P, Deli MA, Sipos Á, Szalai A, Voszka I, Polgár A, Tóth K, Csete M, Nagy G, Gay S, Falus A, Kittel Á, Buzás EI (2011) Detection and isolation of cell-derived microparticles are compromised by protein complexes resulting from shared biophysical parameters. Blood 117 (4):e39-e48. doi:10.1182/blood-2010-09-307595

17. Kolowos W, Gaipl US, Sheriff A, Voll RE, Heyder P, Kern P, Kalden JR, Herrmann M (2005) Microparticles Shed from Different Antigen-Presenting Cells Display an Individual Pattern of Surface Molecules and a Distinct Potential of Allogeneic T-Cell Activation. Scandinavian Journal of Immunology 61 (3):226-233. doi:10.1111/j.1365-3083.2005.01551.x

18. Dweep H, Sticht C, Pandey P, Gretz N (2011) miRWalk - Database: Prediction of possible miRNA binding sites by "walking" the genes of three genomes. Journal of Biomedical Informatics 44 (5):839847. doi:http://dx.doi.org/10.1016/j.jbi.2011.05.002

19. Wahlgren J, Karlson DLT, Glader P, Telemo E, Valadi H (2012) Activated human T cells secrete exosomes that participate in IL-2-mediated immune response signaling. PLOS ONE 10.1371/journal.pone.0049723.

20. Ismail N, Wang Y, Dakhlallah D, Moldovan L, Agarwal K, Batte K, Shah P, Wisler J, Eubank TD, Tridandapani S, Paulaitis ME, Piper MG, Marsh CB (2013) Macrophage microvesicles induce macrophage differentiation and miR-223 transfer. Blood 121 (6):984-995. doi:10.1182/blood-2011-08374793

21. O'Connell RM, Rao DS, Chaudhuri AA, Baltimore D (2010) Physiological and pathological roles for microRNAs in the immune system. Nat Rev Immunol 10 (2):111-122

22. Baj-Krzyworzeka M, Weglarczyk K, Mytar B, Szatanek R, Baran J, Zembala M (2011) Tumourderived Microvesicles Contain Interleukin-8 and Modulate Production of Chemokines by Human Monocytes. Anticancer Research 31 (4):1329-1335

23. Gargalovic PS, Imura M, Zhang B, Gharavi NM, Clark MJ, Pagnon J, Yang W-P, He A, Truong A, Patel S, Nelson SF, Horvath S, Berliner JA, Kirchgessner TG, Lusis AJ (2006) Identification of inflammatory gene modules based on variations of human endothelial cell responses to oxidized lipids. Proceedings of the National Academy of Sciences 103 (34):12741-12746. doi:10.1073/pnas.0605457103

24. Miller YI, Choi S-H, Wiesner P, Fang L, Harkewicz R, Hartvigsen K, Boullier As, Gonen A, Diehl CJ, Que X, Montano E, Shaw PX, Tsimikas S, Binder CJ, Witztum JL (2011) Oxidation-Specific Epitopes Are Danger-Associated Molecular Patterns Recognized by Pattern Recognition Receptors of Innate Immunity. Circulation Research 108 (2):235-248. doi:10.1161/circresaha.110.223875

25. Greenberg ME, Sun M, Zhang R, Febbraio M, Silverstein R, Hazen SL (2006) Oxidized phosphatidylserine-CD36 interactions play an essential role in macrophage-dependent phagocytosis of apoptotic cells. The Journal of Experimental Medicine 203 (12):2613-2625. doi:10.1084/jem.20060370

26. Tait JF, Smith C (1999) Phosphatidylserine Receptors: Role of CD36 in Binding of Anionic Phospholipid Vesicles to Monocytic Cells. Journal of Biological Chemistry 274 (5):3048-3054. doi:10.1074/jbc.274.5.3048

27. Munro S, Thomas KL, Abu-Shaar M (1993) Molecular characterization of a peripheral receptor for cannabinoids. Nature 365 (6441):61-65

28. Casanova M, Blázquez C, Martinez-Palacio J, Villanueva C, Fernández-Acenero M, Huffman J, Jorcano J, Guzmán M (2003) Inhibition of skin tumor growth and angiogenesis in vivo by activation of cannabinoid receptors. The Journal of Clinical Investigation 111 (1):43-50. doi:10.1172/jci16116

29. Fitzcharles M-A, McDougall J, Ste-Marie PA, Padjen I (2012) Clinical implications for cannabinoid use in the rheumatic diseases: Potential for help or harm? Arthritis \& Rheumatism 64 (8):2417-2425. doi:10.1002/art.34522 
30. Gertsch J (2008) Anti-inflammatory cannabinoids in diet. Communicative and Integrative Biology 1 (1):26-28

31. Trexler M, Bányai L, Patthy L (2001) A human protein containing multiple types of proteaseinhibitory modules. Proceedings of the National Academy of Sciences 98 (7):3705-3709. doi:10.1073/pnas.061028398

32. Montojo J, Zuberi K, Rodriguez H, Kazi F, Wright G, Donaldson SL, Morris Q, Bader GD (2010) GeneMANIA Cytoscape plugin: fast gene function predictions on the desktop. Bioinformatics 26 (22):2927-2928. doi:10.1093/bioinformatics/btq562

33. Mostafavi S, Ray D, Warde-Farley D, Grouios C, Morris Q (2008) GeneMANIA: a real-time multiple association network integration algorithm for predicting gene function. Genome Biol 9 (Suppl 1:S4. Epub 2008 Jun 27. doi: 10.1186/gb-2008-9-s1-s4)

34. Warde-Farley D, Donaldson SL, Comes O, Zuberi K, Badrawi R, Chao P, Franz M, Grouios C, Kazi F, Lopes CT, Maitland A, Mostafavi S, Montojo J, Shao Q, Wright G, Bader GD, Morris Q (2010) The GeneMANIA prediction server: biological network integration for gene prioritization and predicting gene function. Nucleic Acids Research 38 (suppl 2):W214-W220. doi:10.1093/nar/gkq537 35. Mootha VK, Lindgren CM, Eriksson K-F, Subramanian A, Sihag S, Lehar J, Puigserver P, Carlsson E, Ridderstrale M, Laurila E, Houstis N, Daly MJ, Patterson N, Mesirov JP, Golub TR, Tamayo P, Spiegelman B, Lander ES, Hirschhorn JN, Altshuler D, Groop LC (2003) PGC-1[alpha]responsive genes involved in oxidative phosphorylation are coordinately downregulated in human diabetes. Nat Genet 34 (3):267-273

36. Subramanian A, Kuehn H, Gould J, Tamayo P, Mesirov JP (2007) GSEA-P: a desktop application for Gene Set Enrichment Analysis. Bioinformatics 23 (23):3251-3253. doi:10.1093/bioinformatics/btm369

37. Subramanian A, Tamayo P, Mootha VK, Mukherjee S, Ebert BL, Gillette MA, Paulovich A, Pomeroy SL, Golub TR, Lander ES, Mesirov JP (2005) Gene set enrichment analysis: A knowledgebased approach for interpreting genome-wide expression profiles. Proceedings of the National Academy of Sciences of the United States of America 102 (43):15545-15550. doi:10.1073/pnas.0506580102

38. Liberzon A, Subramanian A, Pinchback R, Thorvaldsdóttir H, Tamayo P, Mesirov JP (2011) Molecular signatures database (MSigDB) 3.0. Bioinformatics 27 (12):1739-1740. doi:10.1093/bioinformatics/btr260

39. Merico D, Isserlin R, Stueker O, Emili A, Bader GD (2010) Enrichment Map: A Network-Based Method for Gene-Set Enrichment Visualization and Interpretation. PLoS ONE 5 (11):e13984 


\section{Figure legends}

Figure 1. Determination of EV quality, composition and size distribution.

A) Transmission electron micrograph of CCRF-derived EVs. Transmission electron micrograph of extracellular vesicles pelleted by $100,000 \mathrm{~g}$ for $60 \mathrm{~min}$ from cell-free supernatants of CCRF cells. A Hitachi 7100 electron microscope equipped with a Megaview II (lower resolution, Soft Imaging System) digital camera were used to acquire the images.

B) IZON qNano analysis of the size distribution and concentration of extracellular vesicles. Celldepleted CCRF supernatants, containing EVs, were analysed using an NP200 membrane of IZON qNano, at a strech value of $47 \mathrm{~mm}, 120 \mathrm{nA}$ current and $10 \mathrm{~cm}$ water pressure. At least 500 particles were detected. Calibration was performed using known concentration of beads CPC200C (from IZON) diluted 1:1000 in RPMI. The concentration of particles was $2 \times 10^{\wedge} 8$ particles $/ \mathrm{ml}$. The size range was between 170-1250 nm, with a mean diameter of $380 \mathrm{~nm}$, and a mode diameter of $270 \mathrm{~nm}$.

Figure 2. Significant gene expression changes based ANOVA analysis of the microarray data, using GeneSpring.

A) Venn diagram demonstrating the number of significantly up- or downregulated genes (ANOVA, $\mathrm{p}<0.05)$ after each treatment. Upregulation is indicated by red, downregulation by blue arrows.

B) A list of genes showing the names of significantly up- or downregulated genes $($ ANOVA, $<<0.05)$ after each treatment. Among the genes significantly regulated by EVs there were some genes associated with vesicular trafficking. The multivalent protease inhibitor WFIKKN1 was one of the genes significantly upregulated by EVs. The protein product of this gene has been proposed to act as an inhibitor of serine proteases and metalloproteases [31]. A few genes involved in promoting inflammation, such as CXCL14, a potent neutrophil chemoattractant, as well as TBXAS1 were downregulated by treatment with EVs.

Figure 3. Heatmap of gene expression changes and clusters of gene interaction patterns.

In order to generate a heatmap of gene expression changes, we used hierarchical clustering on gene entities with Pearson's Centered similarity measure and centroid linkage rule. Individual clusters of genes showing similar changes in expression pattern upon treatment were generated using K-means clustering. Here, genes differentially expressed after any one of the treatments (ANOVA, p<0.05), are hierarchically clustered based on the pattern of effects. Upregulation is indicated by red, downregulation by blue colour, whereas yellow represents no change compared to control. 
Figure 4. Network analysis of genes modulated by a combined EVs+TNF treatment

\section{A) Interaction network of genes modulated by EV+TNF treatment compared with TNF} treatment alone. Based on the results of the microarray, GeneMania plugin [32-34] for Cytoscape was used to find and visualize functional clusters of significantly altered genes. Gene sets showing significant alteration in any one of the three treatments compared to control (pairwise ANOVA) were queried for co-expression, protein-protein interactions, shared domains and co-localization. The program was set to find at maximum 20 relevant attributes. This interaction network shows genes significantly differentially expressed after a combined EVs+TNF treatment compared to treatment with TNF alone. Upregulation is indicated by red, downregulation by blue colour, the left side of the nodes is coloured according to gene expression after TNF treatment, the right side according to gene expression after the combined EVs+TNF treatment.

B. Network of GO terms, only enriched after a combined, EVs+TNF treatment, but not TNF treatment alone. Beyond single-gene analysis, Gene Set Enrichment Analysis (GSEA) was also applied, using the standard implementation of the method by Subramanian, Tamayo, et al [35-37], currently called GSEA v3.1, available from the Broad Institute via the web (http://www.broadinstitute.org/gsea/index.jsp). Given the limited number of conditions, we did all analyses with 1000 permutations based on the genotype. Gene sets were obtained from the c2, c3, c4 and c5 branches of the Molecular Signatures Database (MSigDB v3.1) [38], excluding gene sets that contain less than 15 or more than 500 entities. As a screening test, we investigated all datasets in the corresponding branches of MSigDB and counted the number of gene sets showing a significant enrichment at a false detection rate $(\mathrm{FDR})<25 \%$ at nominal $\mathrm{p}$ value $<5 \%$. GSEA results of Gene Ontology (GO) terms (c5) were visualized using Cytoscape and its Enrichment Map [39]. For network generation in Enrichment Map, we used the standard settings (p-value cut-off 0.005; FDR cut-off 0.1; Overlap coefficient 0.5; Combined constant 0.5). Here, the top 60 genes of those sets only enriched after the combined EVs+TNF treatment, but not after TNF treatment alone, were plotted against related, enriched GO terms. In the figure, genes are connected to the relevant terms. Colour and node size represent expression after a combined EVs+TNF treatment. Upregulation is indicated by red, downregulation by blue colour.

Figure 5. Validation of the microarray results using Taqman assays, an IL-8 ELISA assay and using purified MVs and TNF.

Changes in mRNA and protein levels of selected genes upon different treatments were detected by Taqman real-time PCR and ELISA assays. A) The mRNA level expression of CNR2, CD36, IL-8 and 
CCL2 in the four treatments were detected by Taqman real-time PCR assays (Mean \pm SEM, n=4). For these assays, the original RNA samples also utilised for the microarray analyis, were used. B) Protein concentration of IL-8 in the supernatant of U937 cells following the four treatments, as detected by a commercially available ELISA assay (Mean \pm SEM, $n=4$ ). Data were analysed by repeated measures ANOVA with Tukey's post test. Differences with $\mathrm{p}<0.05$ were considered statistically significant. One asterisk indicates a statistically significant difference at the $\mathrm{p}<0.05$ level, two asterisks indicate a statistically significant difference at the $\mathrm{p}<0.01$ level and three asterisks indicate a statistically significant difference at the $\mathrm{p}<0.001$ level. C) In order to prove the existence of a cross-talk between EVs and cytokines, we used purified MV populations, resuspended in RPMI, to treat U937 cells. The gene expression levels of IL-8 were monitored in the treated cells, using Taqman gene expression assays (Mean \pm SEM, $n=3$ ). Data were analysed by repeated measures ANOVA with Tukey's post test. Differences with $\mathrm{p}<0.05$ were considered statistically significant. Three asterisks indicate a statistically significant difference at the $\mathrm{p}<0.001$ level. 


\section{Figures}

A
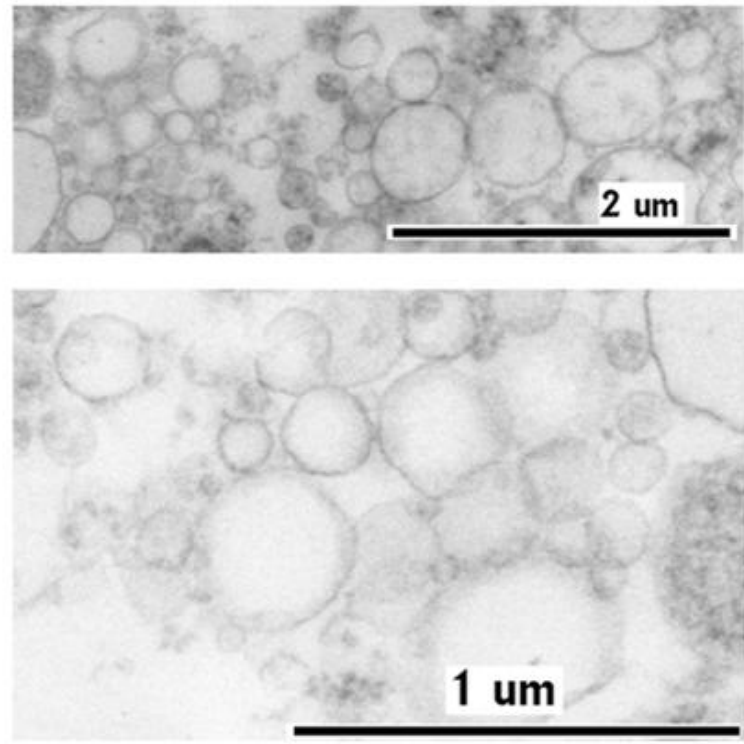

B

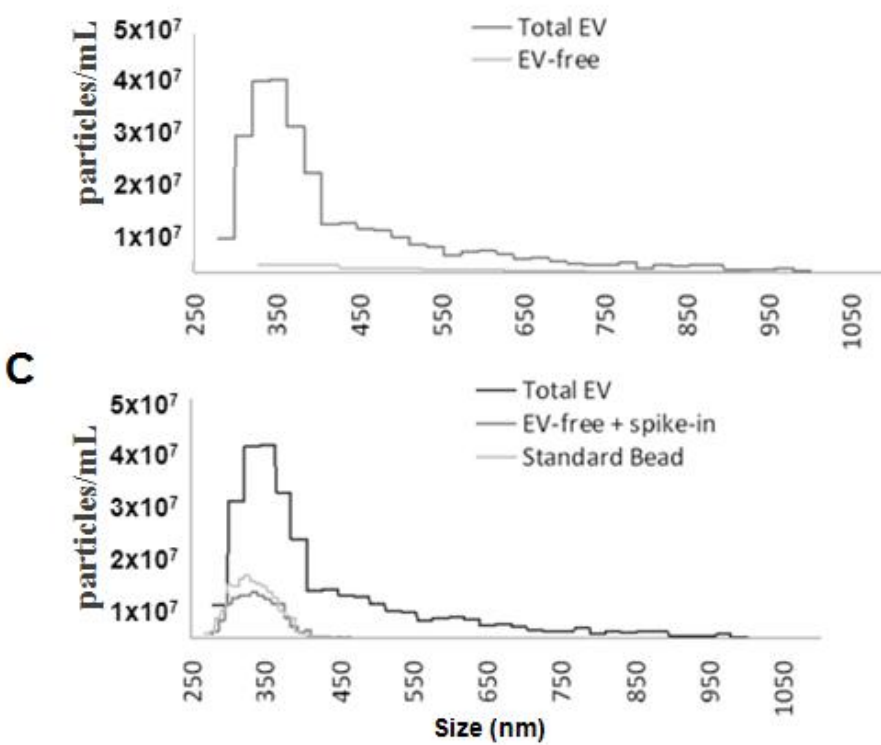

A

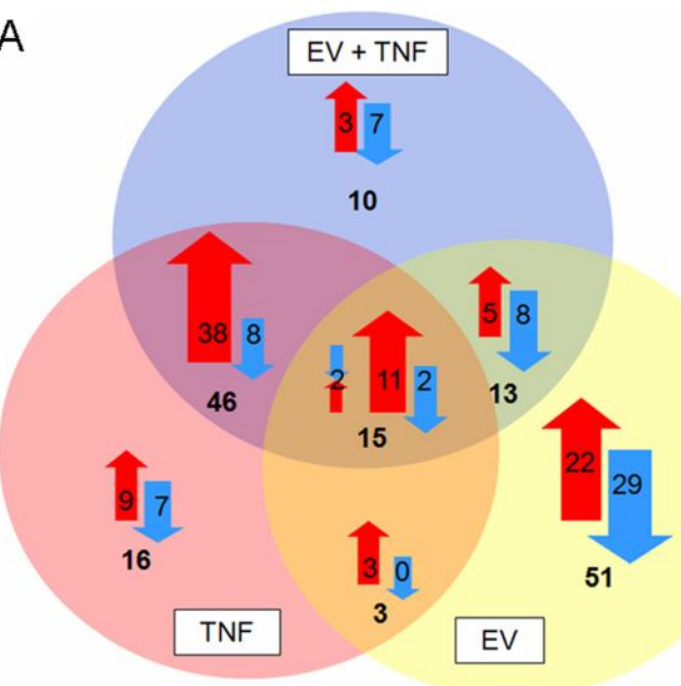

B

\begin{tabular}{|c|c|c|c|}
\hline$\uparrow \mathrm{TNF}$ & $\downarrow$ TNF & $\uparrow \mathrm{EVs}+\mathrm{TNF}$ & EVs+TNF \\
\hline $\begin{array}{l}\text { CD36, CD48, CD74, } \\
\text { EML1, ILA1, NFKKIE, } \\
\text { STXAA, TNFAIPB, ZFFX3 }\end{array}$ & $\begin{array}{l}\text { BLNK, CCDC11, CTSS, } \\
\text { ICAM5, POLD3, SRGN, } \\
\text { ZMAT1 }\end{array}$ & $\begin{array}{l}\text { KLF6, PPP1R15A, } \\
\text { TOR3A }\end{array}$ & $\begin{array}{l}\text { ABLIM1, C5orf39, } \\
\text { CCDC121, GOLPH3L, } \\
\text { L3MBTL1, RDM1, } \\
\text { SLC40A1 } \\
\end{array}$ \\
\hline$\uparrow \mathrm{EVs}$ & $\downarrow$ EVs & $\uparrow \mathrm{TNF}, \mathrm{EV} s+\mathrm{TNF}$ & $\downarrow \mathrm{TNF}, \mathrm{EV} s+\mathrm{TNF}$ \\
\hline \multirow{3}{*}{ 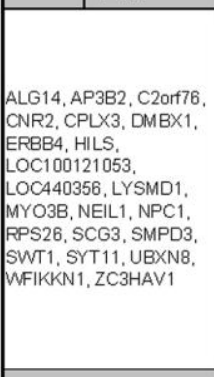 } & \multirow{3}{*}{ 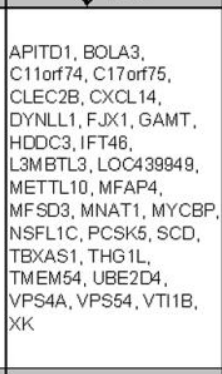 } & \multirow{3}{*}{ 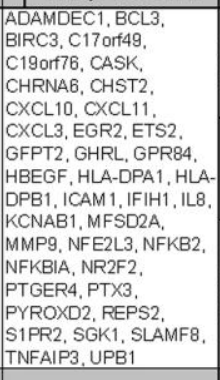 } & $\begin{array}{l}\text { C20orf103, CD160, FOS, } \\
\text { IGLL1, LOC100507057, } \\
\text { PLAC8, RBM22 }\end{array}$ \\
\hline & & & $\uparrow$ all treatments \\
\hline & & & $\begin{array}{l}\text { BCL2A1, CCL2, CHIIL1, } \\
\text { CXCL2, CYP1A1, FCAR, } \\
\text { GPR68, HIVEP1, RBMS3, } \\
\text { RELB, RGS1 } \\
\end{array}$ \\
\hline$\uparrow E V s, E V s+T N F$ & $\downarrow \mathrm{EVs}, \mathrm{EVs}+\mathrm{TNF}$ & $\uparrow \mathrm{TNF}$, Evs & $\downarrow$ all treatments \\
\hline $\begin{array}{l}\text { C13orf31, CD82, } \\
\text { DoPP1, WDR81, } \\
\text { ZFYVE26 }\end{array}$ & $\begin{array}{l}\text { AKAP7, C110r83, } \\
\text { C170rf 108, } \\
\text { LOC10050176, MDP1, } \\
\text { MT18, NKAPP1, NKX2-1 }\end{array}$ & $\begin{array}{l}\text { IL17RA, PLA2G4C, } \\
\text { STX11 }\end{array}$ & $\begin{array}{l}\text { (downregulation) } \\
\text { (GLL5, RBKS: } \\
\text { (discordant) } \\
\text { CITA, ZMIZ2 }\end{array}$ \\
\hline
\end{tabular}




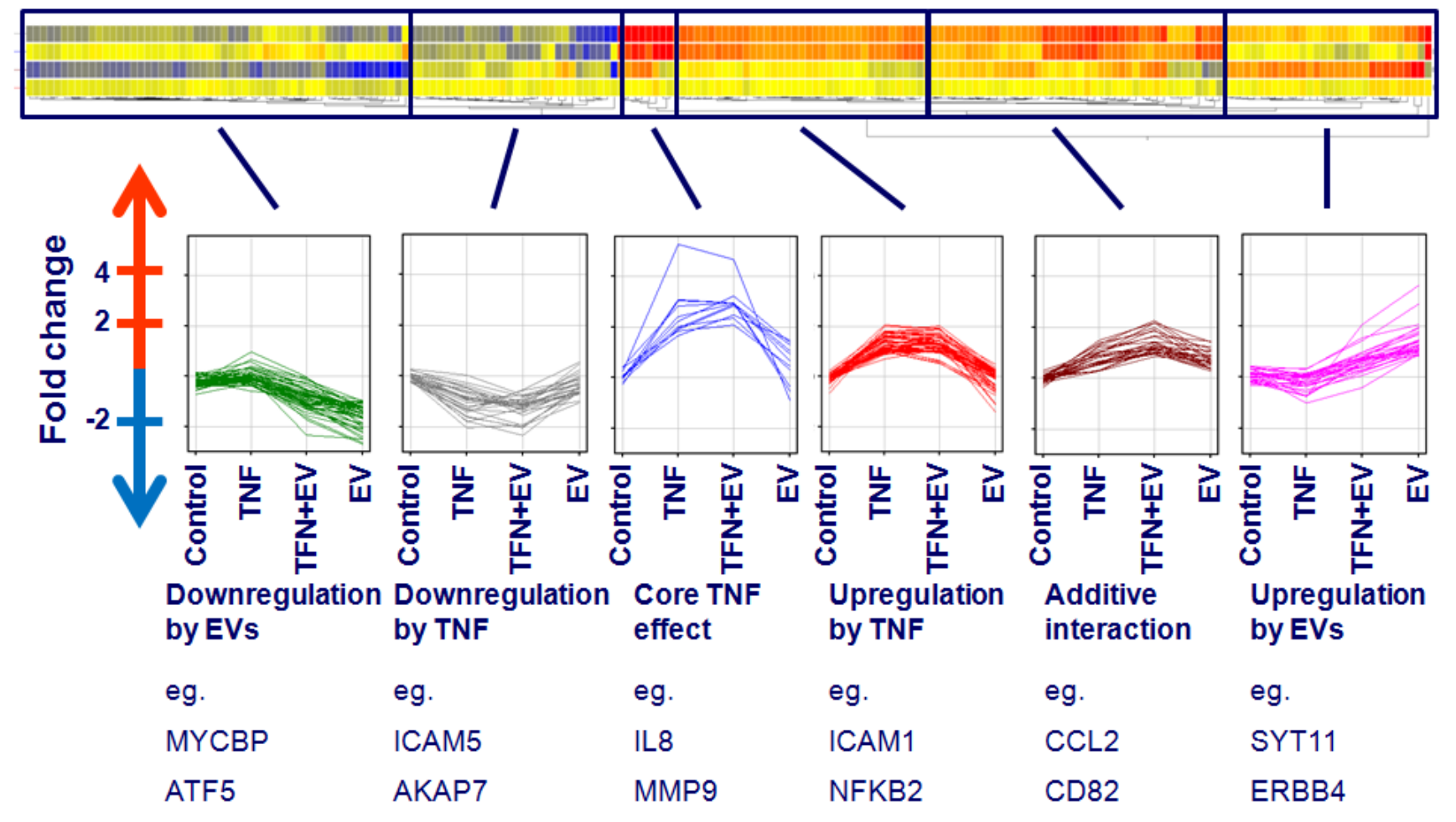


A

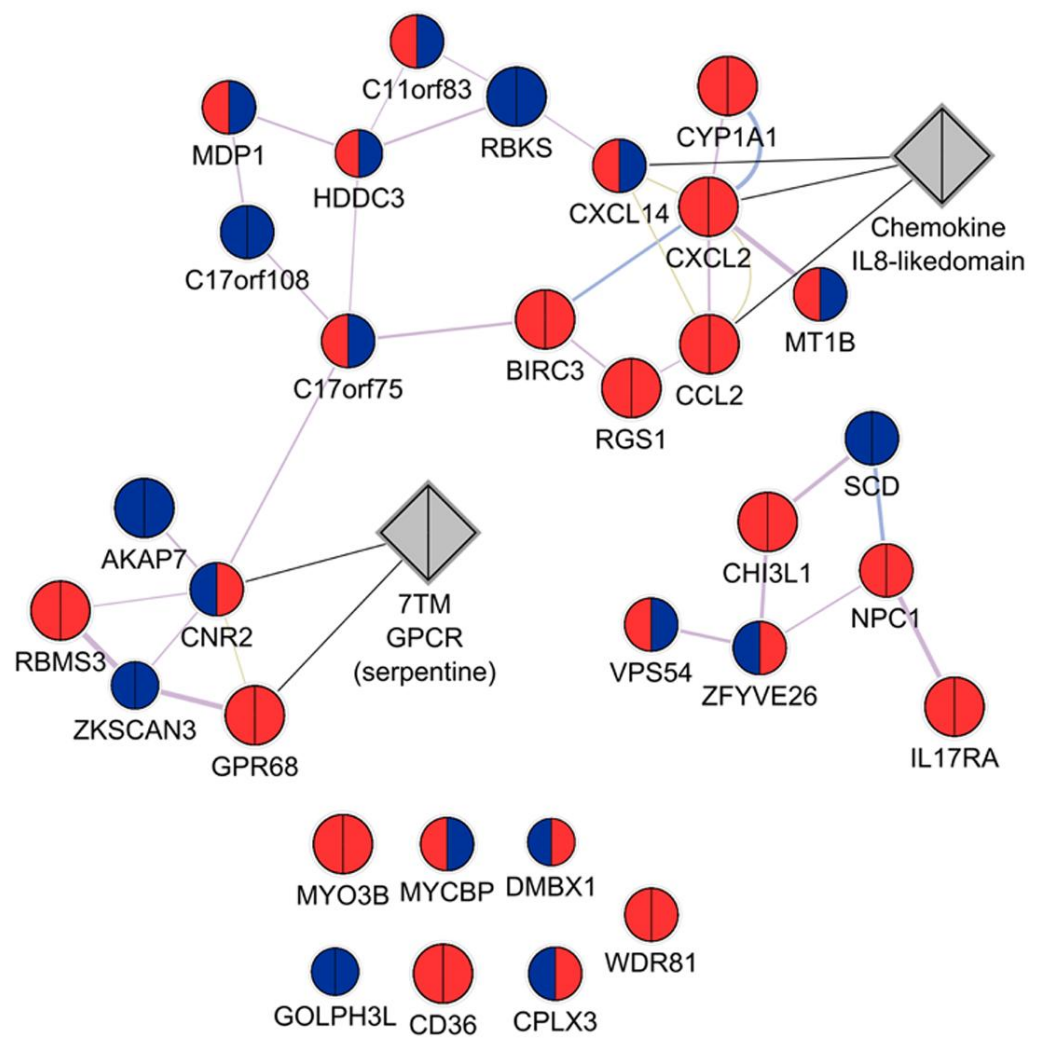

B

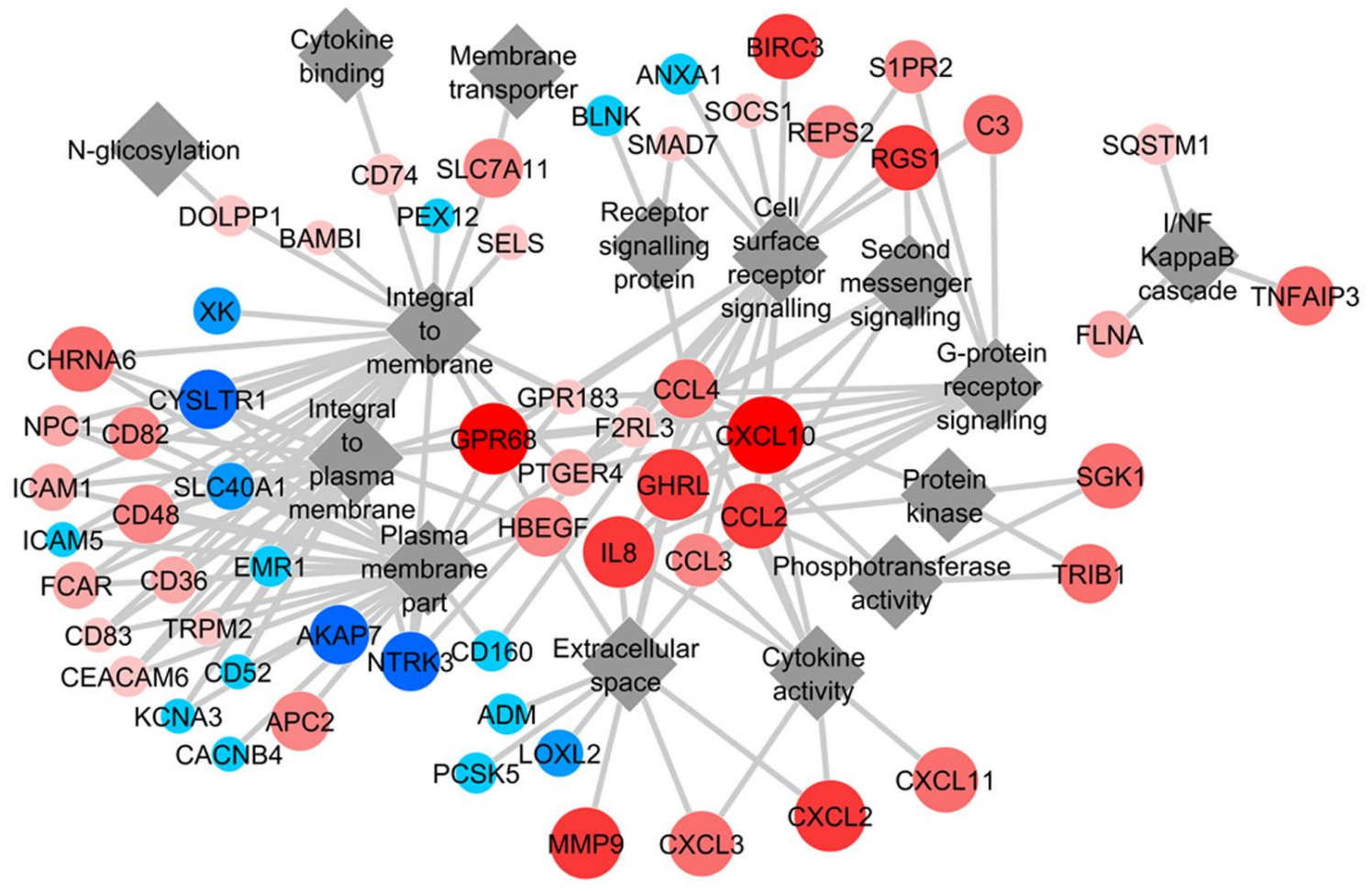


A
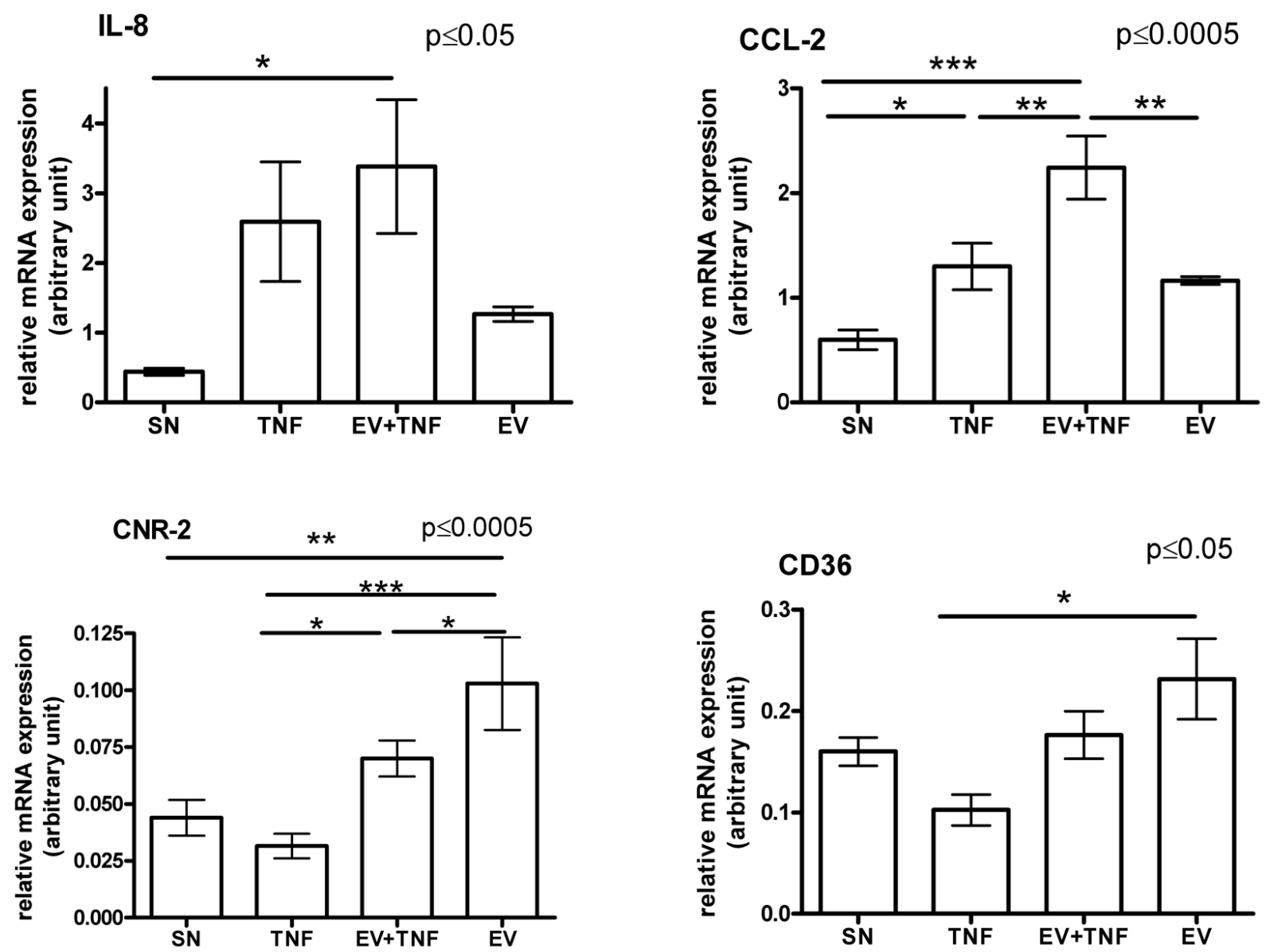

B
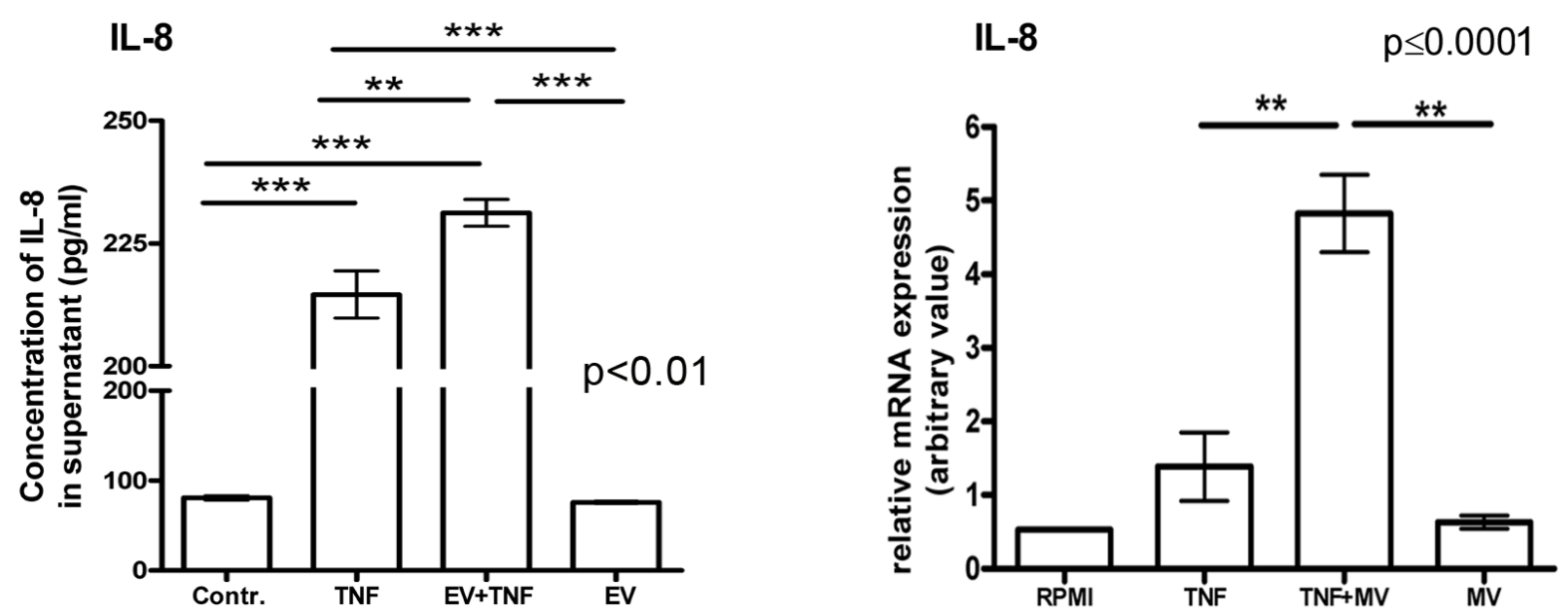

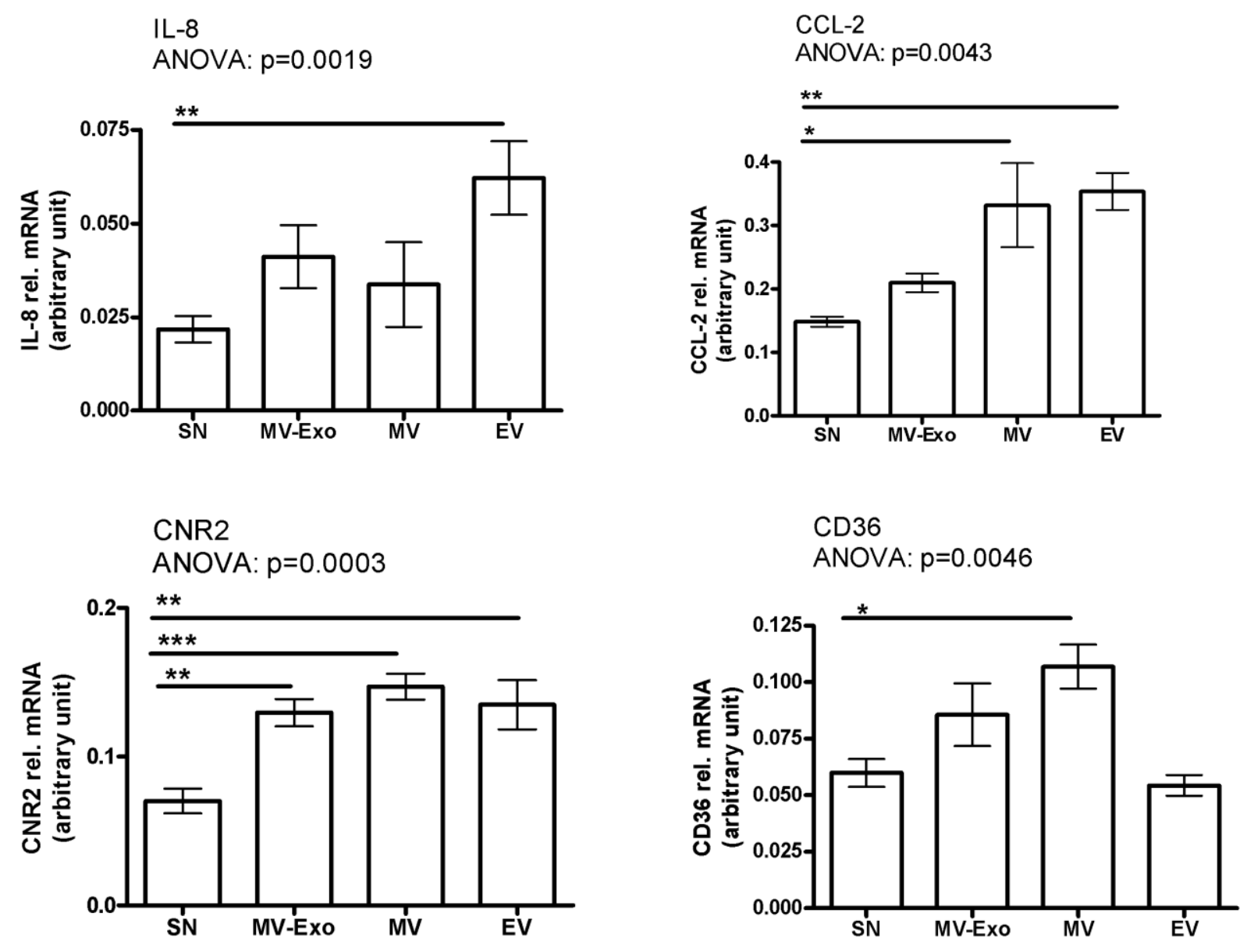

\section{Supplementary figures}
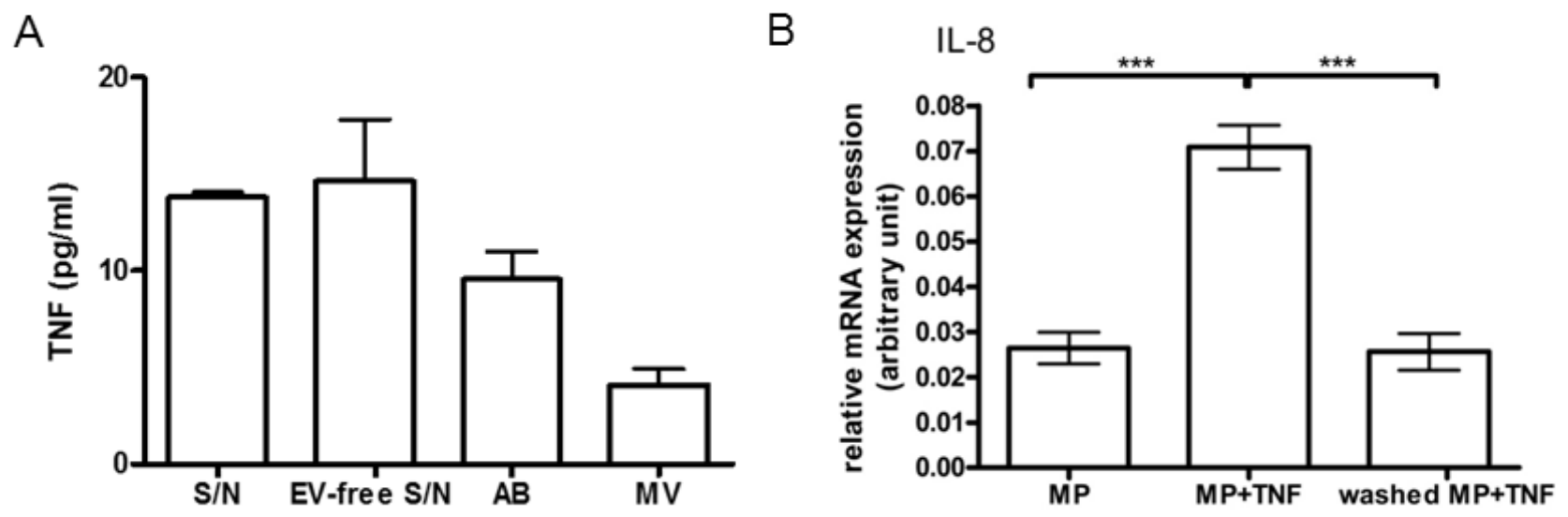
A

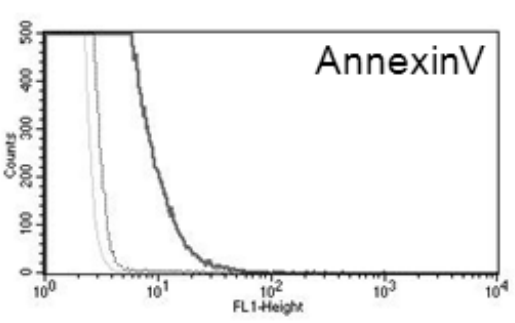

D

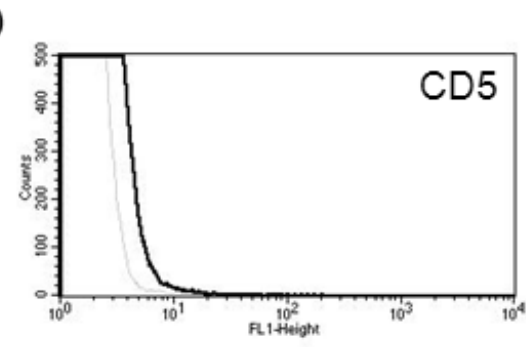

CD82
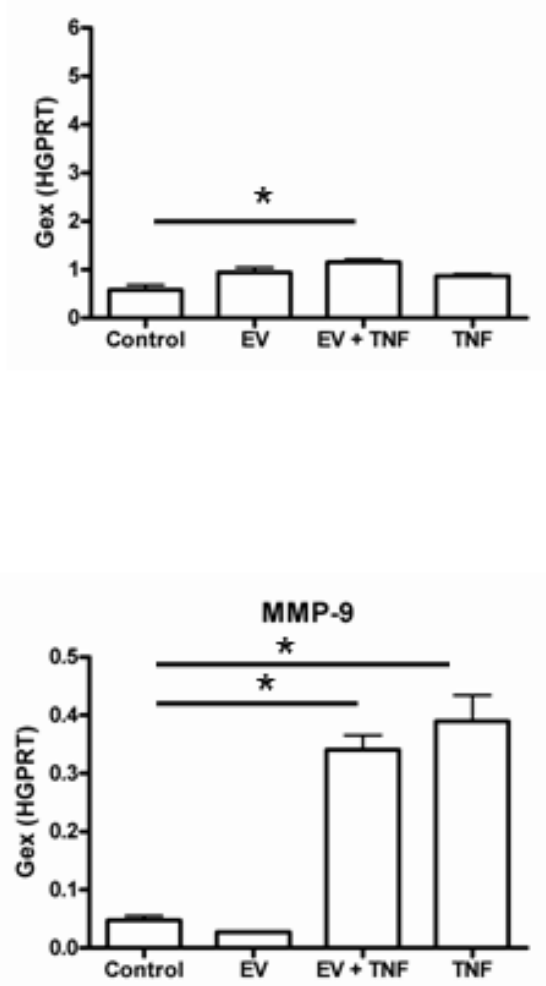

B

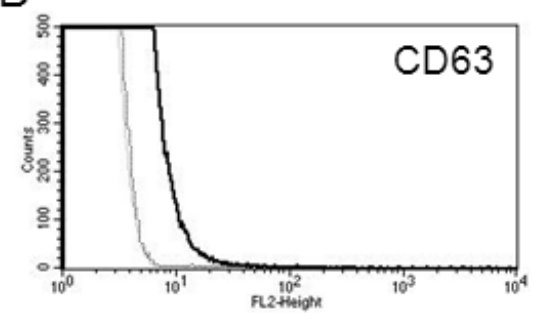

E

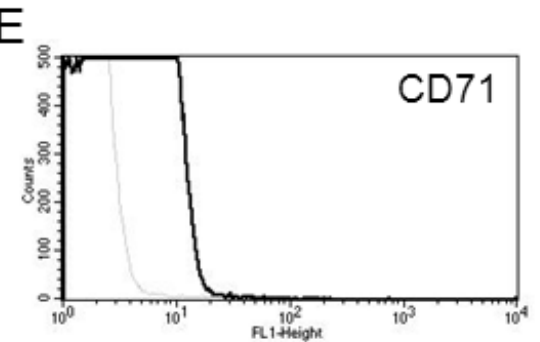

ICAM-1

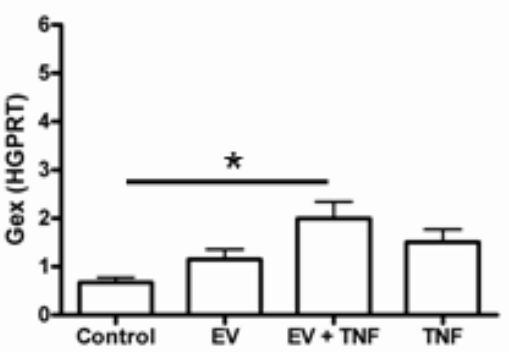

C

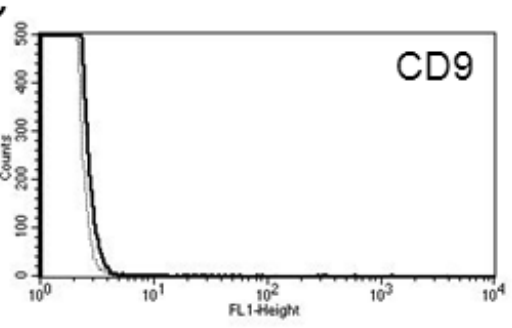

F

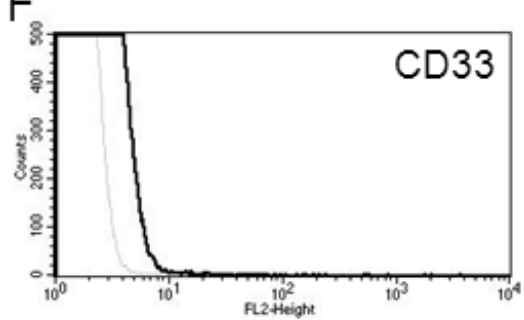

NPC-1

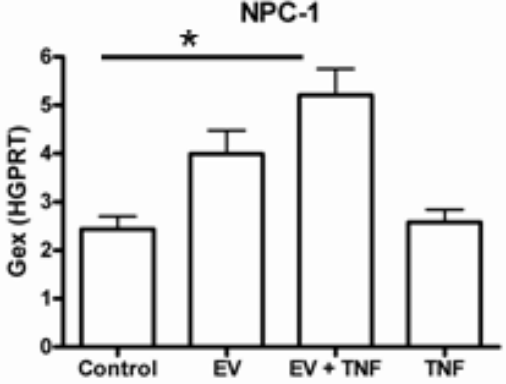

SMPD-3

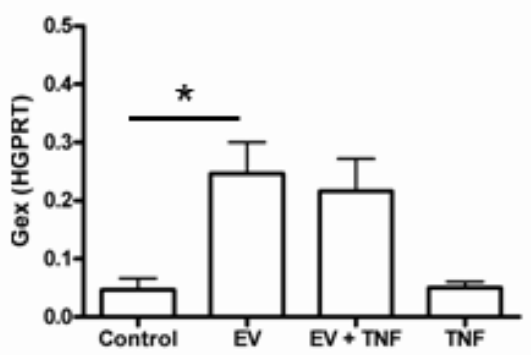

CXCL-2

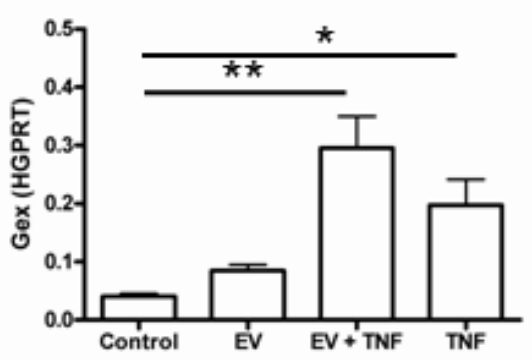




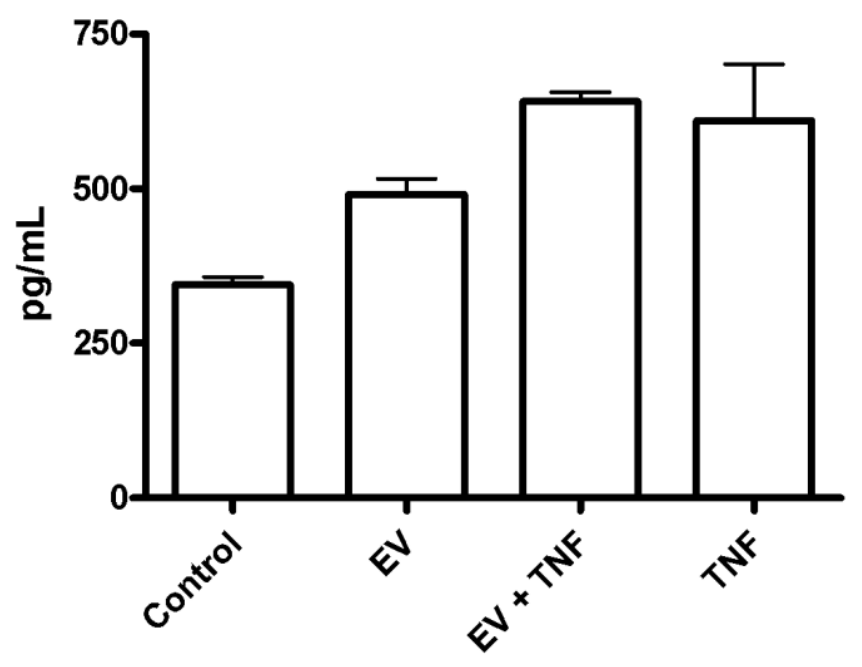

Chemotactic activity of conditioned medium

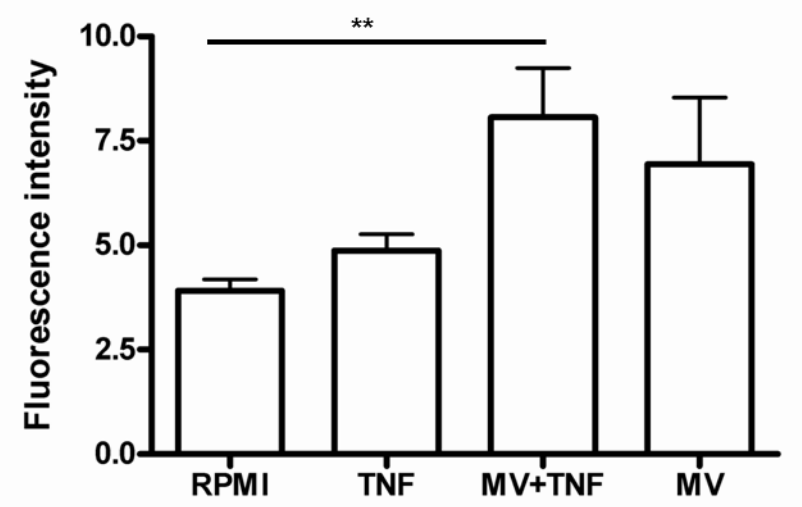

